\title{
Genitourinary infection with Ureaplasma urealyticum in women attending a sexually transmitted diseases clinic
}

\author{
JENNIFER M HUNTER, * HUGH YOUNG, $\uparrow$ AND A B HARRIS $†$ \\ From the *Department of Genitourinary Medicine, Edinburgh Royal Infirmary, and the +Department of \\ Bacteriology, University of Edinburgh, Edinburgh
}

SUMMARY Ureaplasma urealyticum was detected in the cervix of $49 \cdot 9 \%$ and in the urine of $47 \cdot 7 \%$ of women attending a department of genitourinary medicine. Isolation of $U$ urealyticum was not related to diagnosis, nor was there any association between the presence of the organism $ᄋ$ and any symptoms or signs of genital tract disease. Fewer organisms were detected in the cervix of women who had a concurrent infection with Chlamydia trachomatis than in women who had not. A pathological role for $U$ urealyticum has not been established.

\section{Introduction}

Non-gonococcal urethritis (NGU) is now the commonest sexually transmitted disease in Britain. ${ }^{12}$ The substantial evidence for a causative role for Chlamydia trachomatis in this infection has been reviewed by Taylor-Robinson and Thomas. ${ }^{3}$ An aetiological role for Ureaplasma urealyticum, especially in non-chlamydial NGU, has been suggested, 4-7 but despite evidence from selfinoculation $^{8}$ and chemotherapeutic studies ${ }^{9-11}$ the pathological significance of the organism has yet to be confirmed.

$U$ urealyticum has been detected frequently and in large numbers in sexually active women. ${ }^{12} 13$ Its transmission by sexual contact seems well established, ${ }^{14}$ and the colonisation of the female genital tract with $U$ urealyticum has been related to sexual activity and the number of sexual partners. ${ }^{13} 15$ Although various reports have related $U$ urealyticum infection to impaired fertility, abortion, and low birth weight, ${ }^{1316}$ its pathogenicity in the female genital tract has not yet been established.

This study describes the prevalence of $U$ urealyticum in women attending a clinic for the treatment of sexually transmitted disease and attempts to correlate ureaplasmal infection with signs and symptoms of genital tract disease.

Address for reprints: Dr J M Hunter, Department of Genitourinary Medicine, Black Street, Glasgow 64 0EF

Accepted for publication 5 March 1981

\section{Patients and methods}

The patients studied were women who attended the department of genitourinary medicine at the Royal Infirmary, Edinburgh, for the first time between April and September 1980 and women who had attended the clinic previously but who presented $\stackrel{\mathbb{Q}}{\mathscr{Q}}$ during this period with a new complaint. All such $\overrightarrow{\vec{P}}$ women who presented between 9 am and 12 noon 3 Monday to Friday were included unless they had received antibiotic therapy during the six weeks before their first visit.

\section{DIAGNOSTIC PROCEDURES \\ Gonorrhoea}

Specimens for microscopy were taken from the urethra and cervix. Specimens for culture were taken from the urethra, cervix, rectum, and throat (where indicated) and were plated directly on to Modified New York City medium. ${ }^{17}$ After incubation at $36^{\circ} \mathrm{C}$ for 24 hours Neisseria gonorrhoeae was identified by $N$ rapid carbohydrate utilisation tests or delayed $N$ immunofluorescence or both. ${ }^{18}$

\section{Chlamydia trachomatis}

Specimens were taken from the endocervix with sterile cotton-tipped swabs and placed in 2SP medium. They were stored at $-20^{\circ} \mathrm{C}$ for up to three hours and at $-60^{\circ} \mathrm{C}$ for up to three days before being cultured. Isolation was carried out by the $\vec{D}$ method of Thomas et al $^{19}$ with cycloheximide-treated cells. Infected cells were incubated for three days at 
$35^{\circ} \mathrm{C}$ and the coverslips stained with iodine to detect the glycogen inclusions.

\section{Ureaplasma urealyticum}

Urine. The first $10-15 \mathrm{ml}$ of voided urine were collected in a sterile universal container and stored for up to three hours at room temperature before being transported to the laboratory and processed as described by Young et al. ${ }^{12}$ Results were expressed as total colour-changing units (ccu) present in the initial sample.

Cervix. Endocervical swabs were placed in $1.8 \mathrm{ml}$ of TALC colour change medium ${ }^{12}$ contained in bijou bottles for transport to the laboratory. On arrival, the swab was agitated in the medium and liquid expressed from the swab before it was removed from the bottle. A $200-\mu$ l volume was used to initiate a series of 10 -fold dilutions up to $10^{10}$ in $1 \cdot 8-\mathrm{ml}$ volumes of TALC medium. The medium from which the swab had been removed was considered to be a $1 / 10$ dilution of cervical material.

\section{Other STDs}

Genital herpes simplex virus infection was confirmed by viral isolation and serum antibody titres. The presence of pox virus particles in molluscum contagiosum was established by electron microscopy. Vaginal secretions were examined microscopically for Trichomonas vaginalis and yeasts. Other STDs were diagnosed clinically.

\section{DIAGNOSTIC GROUPS}

Patients were assigned to one of four diagnostic groups:

(1) Women from whom $N$ gonorrhoeae was isolated;

(2) Women who were identified as consorts of men with NGU;

(3) Women with any other STD; and
(4) Women with no evidence of STD; this group was subdivided into women who had conditions which required treatment and those which did not. Allocation to any diagnostic group was made independently of the culture results for $C$ trachomatis and $U$ urealyticum.

\section{CLINICAL APPEARANCE OF THE CERVIX}

The difficulties associated with interpreting clinical signs in the cervix have been discussed in detail by Rees and her co-workers, ${ }^{20}$ who described a method for the standardised reporting of the clinical appearance of the cervix.

We used a similar method with the following classifications: (a) clinically healthy cervix; (b) simple cervical ectopy; and (c) cervicitis (congested oedematous cervix or cervical mucopus or pus or both).

\section{STATISTICAL ANALYSIS}

Statistical analysis was carried out using the $\chi^{2}$ test with Yates's correction.

\section{Results}

Five hundred and twenty-eight women participated in the survey. Valid results for ureaplasmal isolation were obtained from the cervix in 413 , from the urine in $\mathbf{3 7 5}$, and from both sites in 359 women. Several women from whom cervical specimens were obtained were unable to pass urine at their initial visit, and a batch of almost 100 specimens from both sites was contaminated accidentally.

\section{PREVALENCE}

$U$ urealyticum was isolated from the cervix in $206 / 413(49 \cdot 9 \%)$ of women and from the urine in $179 / 375(47 \cdot 7 \%)$. Ureaplasmas were detected with equal frequency among all diagnostic groups (table I). The isolation rate was not affected by age. $U$

TABIE 1 Prevalence of ureaplasmas in the cervix and urine in relation to diagnosis

\begin{tabular}{|c|c|c|c|c|c|c|c|c|c|c|c|c|c|c|}
\hline \multirow[b]{3}{*}{ Diagnosis } & \multicolumn{7}{|l|}{ Cervix } & \multicolumn{7}{|l|}{ Urine } \\
\hline & \multirow{2}{*}{$\begin{array}{l}\text { Total } \\
\text { No of } \\
\text { patients }\end{array}$} & \multicolumn{2}{|c|}{$\begin{array}{l}\text { Ureaplasma } \\
\text { - positive }\end{array}$} & \multicolumn{2}{|c|}{ With $<100^{5}$ ccu } & \multicolumn{2}{|c|}{ With $\geqslant 10^{5}$ ccu } & \multirow{2}{*}{$\begin{array}{l}\text { Total } \\
\text { No of } \\
\text { patients }\end{array}$} & \multicolumn{2}{|c|}{$\begin{array}{l}\text { Ureaplasma } \\
\text { - positive }\end{array}$} & \multicolumn{2}{|c|}{ With $<10^{5}$ ced } & \multicolumn{2}{|c|}{ With $\geqslant 10^{5} c c u$} \\
\hline & & No & $\%$ & No & $\%$ & No & $\%$ & & No & $\%$ & No & $\%$ & No & $\%$. \\
\hline Gonorrhoea & 75 & 40 & $53 \cdot 3$ & 25 & $33 \cdot 3$ & 15 & $20 \cdot 0$ & 67 & 32 & $47 \cdot 8$ & 15 & $22 \cdot 4$ & 17 & $25 \cdot 4$ \\
\hline NGU contact & 58 & 29 & $50 \cdot 0$ & 15 & $25 \cdot 9$ & 14 & $24 \cdot 1$ & 56 & 31 & $55 \cdot 4$ & 17 & $30 \cdot 4$ & 14 & $25 \cdot 0$ \\
\hline Other STD & 113 & 51 & $45 \cdot 1$ & 37 & $32 \cdot 7$ & 14 & $12 \cdot 4$ & 96 & 43 & $44 \cdot 8$ & 30 & $31 \cdot 3$ & 13 & $13 \cdot 5$ \\
\hline $\begin{array}{l}\text { Other conditions: } \\
\text { requiring treatment } \\
\text { not requiring }\end{array}$ & 84 & 44 & $52 \cdot 4$ & 32 & $38 \cdot 1$ & 12 & $14 \cdot 3$ & 78 & 38 & $48 \cdot 7$ & 19 & $24 \cdot 4$ & 19 & $24 \cdot 4$ \\
\hline treatment & 83 & 42 & $50 \cdot 6$ & 28 & $33 \cdot 7$ & 14 & $16 \cdot 9$ & 78 & 35 & $44 \cdot 9$ & 21 & $26 \cdot 9$ & 14 & $17 \cdot 9$ \\
\hline Total & 413 & 206 & $49 \cdot 9$ & 137 & $33 \cdot 2$ & 69 & $16 \cdot 7$ & 375 & 179 & $47 \cdot 7$ & 102 & $27 \cdot 2$ & 77 & $20 \cdot 5$ \\
\hline
\end{tabular}

$\mathrm{ccu}=$ colour $-\mathrm{changing}$ units 
urealyticum was found in the cervix of 10 of 30 women over 35 years of age compared with 49 of 91 aged 15-19 years $\left(\chi^{2}=3.02 ; 0.1>P>0.05\right)$ and in $45 \cdot 8 \%(11 / 24)$ of the youngest women (aged 15-17 years) compared with $56 \cdot 7 \%(38 / 67)$ of those aged $18-19$ years $\left(\chi^{2} 0 \cdot 46 ; P=0 \cdot 5\right)$. Large numbers $\left(\geqslant 10^{5}\right.$ ccu) of ureaplasmas were present in the cervix in $16.7 \%$ and in the urine in $20.5 \%$ of women. The number of ureaplasmas present in either site was not related to age or diagnosis.

There was a significant correlation between isolation of ureaplasmas from the cervix and from the urine $\left(\chi^{2}=204 ; \mathrm{P}<0.001\right) ; 46.2 \%$ of women had positive results in both sites, $6 \cdot 1 \%$ in the cervix alone and $5.8 \%$ in the urine alone; $41.8 \%$ had negative results in both sites. This association was also quantitative; $45.3 \%$ of women had ureaplasmas present in both urine and cervix in numbers $\geqslant 10^{5} \mathrm{ccu}$ and $30 \%$ had small numbers at both sites (table II). In only four $(1 \cdot 1 \%)$ women were large numbers of ureaplasmas detected at one site if the other showed no growth.

TABLE $11 U$ urealyticum isolation in urine and cervical specimens

\begin{tabular}{lrrll}
\hline & \multicolumn{5}{c}{ Cervical culture } \\
\cline { 2 - 5 } Urine culture & \multicolumn{5}{c}{+} & + & $<10^{5} \mathrm{ccu}$ & $\geqslant 10^{5} \mathrm{ccu}$ \\
\hline Negative & 166 & 22 & 21 & 1 \\
Positive & 21 & 150 & 96 & 54 \\
$<10^{5} \mathrm{ccu}$ & 18 & 77 & 68 & 9 \\
$\geqslant 10^{5} \mathrm{ccu}$ & 3 & 73 & 28 & 45 \\
\hline
\end{tabular}

$\mathrm{ccu}=$ colour-changing units

$+=$ ureaplasma-positive; $-=$ ureaplasma-negative

\section{RELATION OF UREAPLASMAS TO SYMPTOMS}

\section{AND SIGNS}

In 179 women in whom other STDs were excluded the presence of $U$ urealyticum was analysed in relation to symptoms and signs of genital tract disease. No significant association was found, either quantitatively or qualitatively, between the presence of ureaplasmas in the cervix or urine and any symptom or sign (tables III and IV). In particular, large numbers of ureaplasmas were as common in those with a healthy cervix as in those with cervicitis. o Of 34 women in whose urine $U$ urealyticum was $\Rightarrow$ present in numbers $\geqslant 10^{5} \mathrm{ccu}$, three $(8 \cdot 8 \%) \mathrm{G}$ complained of dysuria compared with $11 / 89(12 \cdot 4 \%)$ women whose urine was ureaplasma-negative.

\section{CONCURRENT CHLAMYDIAL INFECTIONS}

Ureaplasmas were detected in the cervix of 43/81 $(53.1 \%)$ of chlamydia-positive women and in $157 / 319(49 \cdot 2 \%)$ of chlamydia-negative women (table V). Numbers $\geqslant 10^{5}$ ccu were detected in nine $(11 \cdot 1 \%)$ chlamydia-positive women and in $17.9 \%$ $(57 / 319)$ of chlamydia-negative women. This difference just fails to reach statistical significance at the $0.5 \%$ level $\left(\chi^{2} 2.9 ; 0.1>P>0.05\right)$. If, however, only the groups with the highest incidence of $C \underset{\omega}{\omega}$ trachomatis (contacts of NGU and women with gonorrhoea) are considered, the difference in numbers of ureaplasmas present in chlamydiapositive and chlamydia-negative women is significant (table V; $\chi^{2} 4 \cdot 5 ; 0.05>P>0 \cdot 02$ ). No such difference was noted in women with other conditions, sexually transmitted or otherwise.

The presence of $C$ trachomatis in the cervix was not correlated with the isolation of ureaplasmas from the urine, either quantitatively or qualitatively, in any diagnostic group.

\section{Discussion}

Braun et $a l^{21}$ reported a strong association between the presence of $U$ urealyticum in the cervix and in the urine. Our results confirm this association and demonstrate its quantitative nature. Braun, however, isolated ureaplasmas from the cervix alone in $18 \%$ of patients, whereas in this study ureaplasmas were detected in the cervix alone in only $6 \cdot 1 \%$. A similar number $(5 \cdot 8 \%)$ had positive results in the urine alone; the results suggest that if screening women for the presence of ureaplasmas is a useful investigation, samples from either the urine or the cervix would give equally valid results. Numbers of ureaplasmas $\geqslant 10^{5}$ ccu were detected significantly more often in the urine than in the cervix, but this may simply reflect

TABLE III Frequency of ureaplasmal isolation from the cervix in relation to its clinical appearance

\begin{tabular}{|c|c|c|c|c|c|c|c|}
\hline \multirow[b]{2}{*}{ Clinical appearance } & \multirow{2}{*}{$\begin{array}{l}\text { Total } \\
\text { No of } \\
\text { specimens }\end{array}$} & \multicolumn{2}{|c|}{$\begin{array}{l}\text { Ureaplasima } \\
\text { - positive } \\
\end{array}$} & \multicolumn{2}{|c|}{ With $<10^{5} \mathrm{ccu}$} & \multicolumn{2}{|c|}{ With $\geqslant 10^{5}$ cou } \\
\hline & & No & $\%$ & No & $\%$ & No & $\%$ \\
\hline $\begin{array}{l}\text { Healthy } \\
\text { Simple cervical ectopy only } \\
\text { Vaginitis only } \\
\text { Cervicitis }\end{array}$ & $\begin{array}{l}51 \\
47 \\
23 \\
58\end{array}$ & $\begin{array}{r}27 \\
24 \\
8 \\
31\end{array}$ & $\begin{array}{l}52 \cdot 9 \\
51 \cdot 1 \\
34 \cdot 8 \\
53 \cdot 4\end{array}$ & $\begin{array}{r}17 \\
17 \\
5 \\
17\end{array}$ & $\begin{array}{l}33 \cdot 3 \\
36 \cdot 2 \\
21 \cdot 7 \\
29 \cdot 3\end{array}$ & $\begin{array}{r}10 \\
7 \\
3 \\
14\end{array}$ & $\begin{array}{l}19 \cdot 6 \\
14 \cdot 9 \\
13 \cdot 0 \\
24 \cdot 1\end{array}$ \\
\hline
\end{tabular}

$\mathrm{ccu}=$ colour-changing units 
TABLE IV Ureaplasmal isolation from urine in relation to symptoms

\begin{tabular}{|c|c|c|c|c|c|c|c|}
\hline \multirow[b]{2}{*}{ Symptoms } & \multirow{2}{*}{$\begin{array}{l}\text { Total } \\
\text { No of } \\
\text { specimens }\end{array}$} & \multicolumn{2}{|c|}{$\begin{array}{l}\text { Ureaplasma } \\
\text { - positive }\end{array}$} & \multicolumn{2}{|c|}{ With $<10^{5} \mathrm{ccu}$} & \multicolumn{2}{|c|}{ With $\geqslant 10^{5} \mathrm{ccu}$} \\
\hline & & No & $\%$ & No & $\%$ & No & $\%$ \\
\hline $\begin{array}{l}\text { No symptoms } \\
\text { Vaginal discharge } \\
\text { Genital irritation } \\
\text { Dysuria }\end{array}$ & $\begin{array}{l}71 \\
77 \\
60 \\
19\end{array}$ & $\begin{array}{r}30 \\
41 \\
34 \\
8\end{array}$ & $\begin{array}{l}42 \cdot 3 \\
53 \cdot 2 \\
56 \cdot 6 \\
42 \cdot 1\end{array}$ & $\begin{array}{r}16 \\
23 \\
20 \\
5\end{array}$ & $\begin{array}{l}22 \cdot 5 \\
29 \cdot 9 \\
33 \cdot 3 \\
26 \cdot 3\end{array}$ & $\begin{array}{r}14 \\
18 \\
14 \\
3\end{array}$ & $\begin{array}{l}19 \cdot 7 \\
23 \cdot 4 \\
23 \cdot 3 \\
15 \cdot 8\end{array}$ \\
\hline
\end{tabular}

ccu $=$ colour-changing units

the difference in sampling procedures; an initial specimen of urine may contain a greater proportion of the organisms present than does an endocervical swab.

The overall prevalence of ureaplasmas found in this study $(47.7 \%$ in the urine and $49.9 \%$ in the cervix) is slightly lower than that previously reported in similar populations. ${ }^{12}{ }^{13} \mathrm{We}$ were unable to detect any difference in isolation rates among the various diagnostic groups, and the number of ureaplasmas present was similar in every group. Young et al ${ }^{12}$ reported that women whose consorts had NGU had a significantly higher incidence of ureaplasmal infection, but they were also unable to detect any quantitative differences.

It might have been expected that the organism would occur less frequently among the youngest women, but no difference was found between those aged 15-17 years and the other age groups, presumably because sexual activity is already established in girls of this age attending the clinic. The only age group in which ureaplasmas were isolated less frequently was that over 35 years of age; these women comprised less than $10 \%$ of the study population and the difference was not statistically significant.

The lack of association, quantitative or otherwise, between the presence of ureaplasmas and any sign or symptom of genital tract disease makes a pathological role for the organism in women seem unlikely. In the same series of patients we noted an association between chlamydial infection and the clinical appearance of the cervix. These findings (unpublished observations) are similar to those reported by Rees and her co-workers. ${ }^{20}$

Concurrent infection with $C$ trachomatis seems to affect adversely the number of ureaplasmas detected, although this effect is less clear-cut in women than it was in men with NGU. ${ }^{22}$ The presence of chlamydia may inhibit the multiplication of ureaplasmas, perhaps by preventing their association with cells; alternatively, ureaplasmas may be present in chlamydia-infected cells but are more difficult to detect. Masover et $a l^{23}$ reported that the single identifying property of $U$ urealyticum - the ability to hydrolyse urea-was lost or not expressed after association with mammalian cells in vitro. The mechanism of the association between ureaplasmas and cells in vivo is not known, but the possibility that it might be influenced in some way by the presence of $C$ trachomatis deserves further study.

This study confirms that $U$ urealyticum is common in the urine and cervix of sexually active women, but it has not established a pathological role for the organism.

We thank our medical and non-medical colleagues in the Department of Genitourinary Medicine, Royal Infirmary, Edinburgh, for their help in the collection of specimens and data and in the preparation of this paper. Thanks are also due to Dr John Peutherer, Dr Isabel Smith, and Mr Angus MacAulay, Department

TABLE $\mathrm{V}$ Ureaplasmal and chlamydial isolation in relation to diagnostic groups

\begin{tabular}{|c|c|c|c|c|c|c|c|c|}
\hline \multirow[b]{2}{*}{ Diagnosis } & \multirow{2}{*}{$\begin{array}{l}\text { Chlamydial } \\
\text { isolation }\end{array}$} & \multirow{2}{*}{$\begin{array}{l}\text { Total } \\
\text { No of } \\
\text { specimens }\end{array}$} & \multicolumn{2}{|c|}{$\begin{array}{l}\text { Ureaplasma } \\
\text { - positive }\end{array}$} & \multicolumn{2}{|c|}{ With $<10^{5} \mathrm{ccu}$} & \multicolumn{2}{|c|}{ With $\geqslant 10^{5} \mathrm{ccu}$} \\
\hline & & & No & $\%$ & No & $\%$ & No & $\%$ \\
\hline \multirow[t]{2}{*}{ All groups } & + & 81 & 43 & $53 \cdot 1$ & 34 & $42 \cdot 0$ & 9 & $11 \cdot 1$ \\
\hline & - & 319 & 157 & $49 \cdot 2$ & 100 & $31 \cdot 3$ & 57 & $17 \cdot 9$ \\
\hline \multirow[t]{2}{*}{ Gonorrhoea } & + & 30 & 14 & $46 \cdot 7$ & 11 & $36 \cdot 7$ & 3 & $10 \cdot 0$ \\
\hline & - & 45 & 26 & $57 \cdot 8$ & 14 & $31 \cdot 1$ & 12 & $26 \cdot 7$ \\
\hline \multirow[t]{2}{*}{ NGU Contact } & + & 21 & 12 & $57 \cdot 1$ & 9 & $42 \cdot 9$ & 3 & $14 \cdot 3$ \\
\hline & - & 34 & 16 & $47 \cdot 1$ & 6 & $17 \cdot 6$ & 10 & $29 \cdot 4$ \\
\hline
\end{tabular}

ccu = colour-changing units

$+=$ positive; $-=$ negative 
of Bacteriology, University of Edinburgh, who provided the facilities for the isolation of $C$ trachomatis.

\section{References}

1. Scottish Home and Health Department. Scottish Health Statistics, 1978.

2. Department of Health and Social Security. Extract from the Annual Report of the Chief Medical Officer for the year 1978. Br J Vener Dis 1980;56: 178-81.

3. Taylor-Robinson D, Thomas BJ. The role of Chlamydia trachomatis in genital tract and associated diseases. J Clin Pathol 1980; 33:205-33.

4. Hare MJ, Dunlop EMC, Taylor-Robinson D. Mycoplasmas and non-specific genital infections. Br J Vener Dis 1969;45: 282-6.

5. Paavonen J, Kousa M, Saikku P, Vesterinen E, Jansson E, Lassus A. Examination of men with non-gonococcal urethritis and their sexual partners for Chlamydia trachomatis and Ureaplasma urealyticum. Sex Transm Dis 1978;5:93-6.

6. Bowie WR, Alexander ER, Holmes KK. Etiologies of postgonococcal urethritis in homosexual and heterosexual men. Sex Transm Dis 1978; 5: 151-4.

7. Taylor Robinson D, Evans RT, Coufalik ED, et al. Ureaplasma urealyticum and mycoplasmas in chlamydial and nonchlamydial post-gonococcal urethritis. Br J Vener Dis 1979; 55: $30-5$.

8. Taylor-Robinson D, Csonka GW, Prentice MJ. Human intraurethral inoculation of ureaplasmas. Quart J Med 1977;46: 309-26.

9. Prentice MJ, Taylor-Robinson D, Csonka GW. Non-specific urethritis. A placebo controlled trial of minocycline in conjunction with laboratory investigations. Br J Vener Dis 1976; 52:269-75.

10. Bowie WR, Alexander ER, Floyd JF, Holmes, J, Miller Y, Holmes KK. Differential response of chlamydial and ureaplasma-associated urethritis to sulphafurazole (sulfisoxazole) and aminocyclitols. Lancet 1976; ii: 1276-8.
11. Coufalik ED, Taylor-Robinson D, Csonka GW. Treatment of non-gonococcal urethritis with rifampicin as a means of defining the role of Ureaplasma urealyticum. Br J Vener Dis $1979 ; 55: 36-43$.

12. Young $\mathrm{H}$, Tuach $\mathrm{S}$, Bain SSR. Incidence of Ureaplasma urealyticum in women attending a clinic for sexually transmissible disease. $J$ Infect 1981 (in press).

13. Kundsin RB. Mycoplasmas in humans. Health Lab Sci 1976; 13: $144-51$.

14. McCormack WM, Lee YH, Zimmer SH. Sexual experience and urethral colonisation with genital mycoplasmas. A study in normal men. Ann Intern Med 1973; 78:696-8.

15. McCormack WM, Almeida PC, Bailey PE, Grady EM, Lee YH. Sexual activity and vaginal colonisation with genital mycoplasmas. JAMA 1972;221:1375-7.

16. Stray-Pedersen B, Eng J, Rerkaum TM. Uterine T-mycoplasma colonisation in reproductive failure. $\mathrm{Am}$ Obstet Gynecol 1978; 130:307-11.

17. Young $\mathrm{H}$. Cultural diagnosis of gonorrhoea with modified New York City (MNYC) medium. Br J Vener Dis 1978; 54: 36-40.

18. Young H, Paterson IC, McDonald DR. Rapid carbohydrate utilisation test for the identification of Neisseria gonorrhoeae. Br J Vener Dis 1976; 52: 172-5.

19. Thomas BJ, Evans RT, Hutchison GR, Taylor-Robinson D. Early detection of chlamydial inclusions combining the use of cycloheximide-treated McCoy cells and immunofluorescence staining. J Clin Microbiol 1977;6:285-92.

20. Rees E, Tait IA, Hobson D, Johnson FWA. Chlamydia in relation to cervical infection and pelvic inflammatory disease. In Hobson D, Holmes KK (eds). Non-gonococcal Urethritis and Related Infections. Washington DC: American Society for Microbiology, 1977;67-76.

21. Braun P, Klein JO, Lee YH, Kass EM. Methodologic investigations and prevalence of genital mycoplasmas in pregnancy. J Infect Dis 1970; 121:391-400.

22. Hunter JM, Smith I, Peutherer JF, MacAulay A, Tuach S, Young H. Chlamydia trachomatis and Ureaplasma urealyticum in men attending a clinic for the treatment of sexually transmitted disease. $\mathrm{Br} J$ Vener Dis 1981;57:130-3.

23. Masover GK, Namba M, Hayflick L. Cytotoxic effect of a T-strain mycoplasma (Ureaplasma urealyticum) on cultured normal human cells. Exp Cell Res 1976;99:363-74. 